ARTICLE

DOI: $10.1038 /$ s41467-017-01610-4

\title{
Multi-scale magnetic mapping of serpentinite carbonation
}

\author{
Masako Tominaga (10 1, Andreas Beinlich 2,3,4, Eduardo A. Lima ${ }^{5}$, Maurice A. Tivey ${ }^{6}$, Brian A. Hampton ${ }^{7}$, \\ Benjamin Weiss ${ }^{5} \&$ Yumiko Harigane ${ }^{8}$
}

Peridotite carbonation represents a critical step within the long-term carbon cycle by sequestering volatile $\mathrm{CO}_{2}$ in solid carbonate. This has been proposed as one potential pathway to mitigate the effects of greenhouse gas release. Most of our current understanding of reaction mechanisms is based on hand specimen and laboratory-scale analyses. Linking laboratory-scale observations to field scale processes remains challenging. Here we present the first geophysical characterization of serpentinite carbonation across scales ranging from $\mathrm{km}$ to sub-mm by combining aeromagnetic observations, outcrop- and thin section-scale magnetic mapping. At all scales, magnetic anomalies coherently change across reaction fronts separating assemblages indicative of incipient, intermittent, and final reaction progress. The abundance of magnetic minerals correlates with reaction progress, causing amplitude and wavelength variations in associated magnetic anomalies. This correlation represents a foundation for characterizing the extent and degree of in situ ultramafic rock carbonation in space and time.

\footnotetext{
${ }^{1}$ Department of Geology and Geophysics, Texas A\&M University, College Station, TX 77845-3115, USA. ${ }^{2}$ The Institute for Geoscience Research (TIGeR), Curtin University, Perth 6845, Australia. ${ }^{3}$ Department of Earth, Ocean and Atmospheric Sciences, The University of British Columbia, 2207 Main Mall, Vancouver, BC, Canada V6T 1Z4. ${ }^{4}$ Physics of Geological Processes (PGP), University of Oslo, Oslo 0316, Norway. ${ }^{5}$ Department of Earth, Atmospheric, and Planetary Sciences, Massachusetts Institute of Technology, 77 Massachusetts Avenue, Cambridge, MA 02139, USA. ${ }^{6}$ Department of Geology and Geophysics, Woods Hole Oceanographic Institution, 266 Woods Hole Rd., Woods Hole, MA 02543, USA. ${ }^{7}$ Department of Geological Sciences, New Mexico State University, Las Cruces, NM 88003, USA. ${ }^{8}$ The National Institute of Advanced Industrial Science and Technology, 1-1-1 Umezono, Tsukuba, Ibaraki 305-8568, Japan. Correspondence and requests for materials should be addressed to M.T. (email: masako.tominaga@tamu.edu)
} 
P eridotite serpentinization and carbonation play important roles in facilitating large-scale cycling of volatiles between the atmosphere, hydrosphere, and lithosphere ${ }^{1,} 2$. The uptake of atmospheric and hydrospheric carbon during ultramafic rock carbonation particularly represents a natural analog to geologic carbon sequestration and is considered as one potential pathway to offset anthropogenic $\mathrm{CO}_{2}$ emissions into the Earth's atmosphere ${ }^{3-7}$. Natural carbonation of ophiolite-alpine-type ultramafic rocks forms alteration assemblages known as ophicarbonate, soapstone, and listvenite. These different carbonation products differ in the composition of secondary sheet silicate phases and the abundance of carbonate and thus their bulk rock $\mathrm{CO}_{2}$ content. Listvenite is predominantly composed of carbonate and quartz and represents a desirable product during in situ $\mathrm{CO}_{2}$ sequestration in ultramafic formations. While natural ultramafic rock carbonation may take place over long time scales, its efficiency has yet to be proven on human time scales. Carbonation reaction parameters are extensively investigated by laboratoryscale hydrothermal experiments $8-11$, thermodynamic modeling ${ }^{3,}$ ${ }^{12}$. and natural analog studies ${ }^{13-19}$. However, a scheme that can delineate the carbonation reaction progress in situ has not yet been fully explored and upscaling of reaction parameters from small scale, controlled laboratory experiments to large scale, complex natural processes remains challenging ${ }^{20-22}$. Along the reaction path of hydrothermal alteration of ultramafic rock, silicate mineral replacement reactions concomitantly release Fe for incorporation into secondary oxide, sulfide, and carbonate pha$\operatorname{ses}^{23,24}$. Of particular interest is the production and consumption of magnetite during reaction of ultramafic rock with hydrothermal fluids due to its strong influence on bulk rock magnetic properties $^{25}$. If coherently observable at multiple scales, we propose that changes in rock magnetic properties related to peridotite serpentinization and subsequent carbonation can be linked to distinct steps along the reaction path, and hence that the reaction progress can be monitored by field magnetometry.

In this study, we investigate magnetic anomaly changes related to natural serpentinite carbonation using regional, outcrop-, and thin section-scale magnetometry coupled with microtextural analysis of mineral replacement reactions. The results show that the magnetic character of distinct alteration product assemblages changes in response to the stability of magnetic carrier phases. Progressive serpentinite carbonation is characterized by a transient increase in the magnetic field strength during intermittent carbonation. The final alteration product is almost devoid of magnetic carrier phases and thus characterized by a very weak magnetic field strength. These findings indicate that magnetic field measurements can be used to detect carbonation fronts in the field and to monitor reaction progress in space and time.

\section{Results}

Field relationships. Widespread and near perfect exposure of naturally carbonated serpentinite at the Linnajavri Ultramafic Complex (LUC) in the Upper Allochthon (Köli nappe) of the Norwegian Caledonides represents an excellent natural laboratory to study the effects of ultramafic rock carbonation on changes in geophysical properties at the field scale (Fig. 1). The LUC represents a dismembered ophiolite complex separated from the Precambrian granitic basement by an up to $\sim 6 \mathrm{~km}$ thick pile of greenschist facies metamorphosed sedimentary rocks.

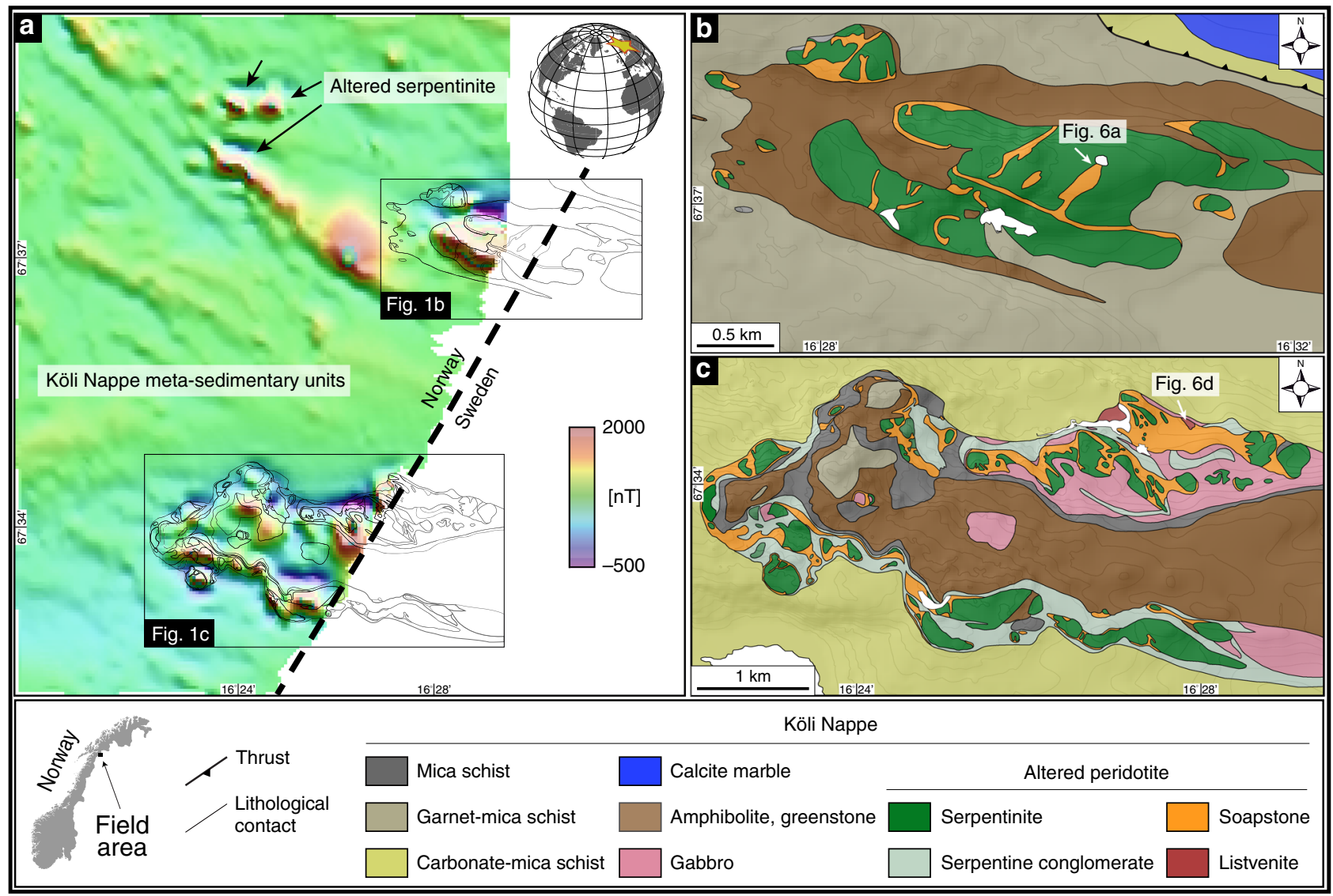

Fig. 1 Aeromagnetic anomaly and geology of the Linnajavri area. a Magnetic anomaly map from the DRAGON aeromagnetic survey of the Linnajavri area showing the location of pristine and altered serpentinite bodies. b, c Geological maps of the Linnajavri Ultramafic Complex (LUC) northern $\mathbf{b}$ and southern parts $\mathbf{c}^{13,27}$. The location of outcrop-scale magnetic survey lines (Fig. 6) is indicated in b, c. Geological and geophysical data do not exist for the blank area 


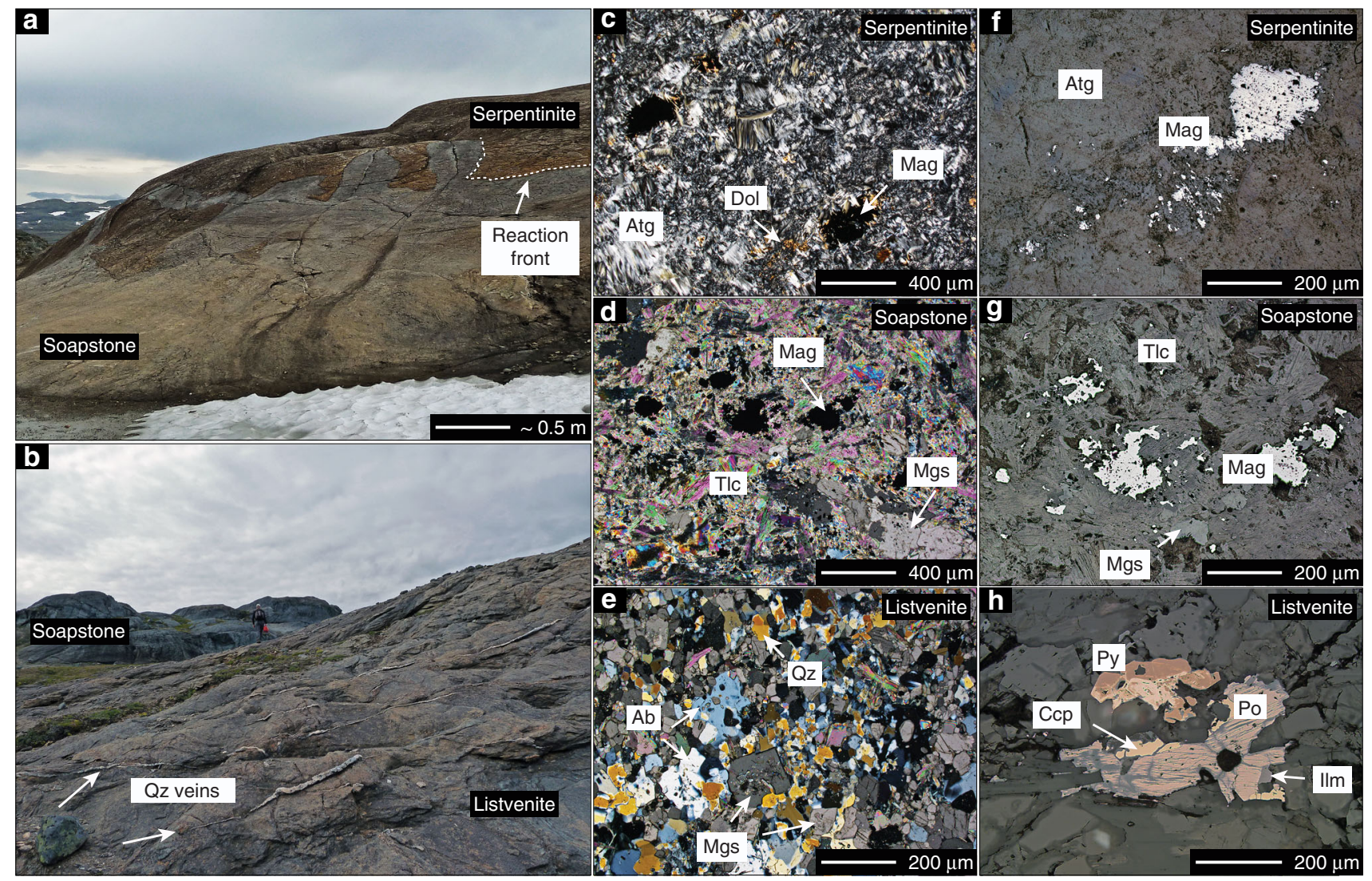

Fig. 2 Field and microtextural relationships of carbonated serpentinite. a Field image of a sharp soapstone reaction front locally following fractures in the serpentinite. b Typical appearance of listvenite in the field with abundant quartz veinlets in front of massive soapstone (person for scale). c-e Representative micrographs of serpentinite, soapstone, and listvenite mineral assemblages in cross-polarized transmitted light. f-h Reflected light micrographs of oxide and sulfide phases in serpentinite, soapstone, and listvenite. Magnetite in serpentinite and soapstone is present as large grains and as fine grained matrix constituent with grain-sizes between $\sim 10 \mu \mathrm{m}$ and $\sim 500 \mu \mathrm{m}$. Listvenite contains in most cases only relict amounts of magnetite and sometime additional pyrite and chalcopyrite together with minor pyrrhotite. Mineral abbreviations follow Whitney and Evans 49

Weichselian glaciation of Scandinavia polished the rock surfaces, resulting in weathering rinds of $<2 \mathrm{~mm}$ thickness.

Previous studies have documented that infiltration of $\mathrm{CO}_{2}$ bearing fluid resulted in the formation of distinct zones of minor serpentine-magnesite (ophimagnesite; $\sim 6.9 \mathrm{wt} \% \mathrm{CO}_{2}$ ), extensive talc-magnesite (soapstone; $14.9 \mathrm{wt} \% \mathrm{CO}_{2}$ ) and quartz-carbonate (listvenite; $29.3 \mathrm{wt} \% \mathrm{CO}_{2}$ ) assemblages from completely serpentinized peridotite during the Caledonian orogeny (Fig. 2a, b; Supplementary Table 1$)^{13}, 26,27$. The soapstone alteration zone is separated by ubiquitously visible sharp reaction fronts, which are indicative of infiltration-driven metasomatic replacement ${ }^{12,} 13,28$, 29. At outcrops, serpentinite carbonation is controlled by structural permeability and concentrated along the basal contact of the ophiolite with the underlying sediments and along faults within the serpentinite. Soapstone alteration zones reach several hundred meters into the ophiolite, while fracture-related alteration selvages in serpentinite are usually $<3 \mathrm{~m}$ wide (Fig. 2a). Formation of the ophimagnesite assemblage is typically restricted to a few centimeters in front of some soapstone fronts. Listvenite is exclusively present above the basal thrust and separated from uncarbonated serpentinite by soapstone (Figs. 1c, 2b). The zonal distribution of the different alteration assemblages indicates that the reaction fronts progressively moved from the basal thrust into the ophiolite, thereby replacing the earlier formed assemblage. Previous work indicated isothermal soapstone and listvenite formation near $250-300{ }^{\circ} \mathrm{C}$ in response to different fluid $\mathrm{CO}_{2}$ activities at a given pressure and temperature ${ }^{13}$ (Fig. 3 ). Thus, the distribution of alteration zones indicates a decreasing fluid $\mathrm{CO}_{2}$ activity from the inferred fluid inlet at the basal thrust into the ophiolite resulting from continuous dilution of the $\mathrm{CO}_{2}$-bearing alteration fluid due to serpentine breakdown and carbonate precipitation along the flow path.

Sample petrography and carbonation reactions. The field relationships are consistent with microtextural analysis of mineral replacement reactions. Serpentinite represents the least altered rock type at the LUC and consists of more than 95 vol.\% of antigorite together with isolated talc-dolomite intergrowths that are pseudomorphically replacing primary clinopyroxene, together with minor tremolite, Cr-spinel, and magnetite (Fig. 2c, f). Soapstone fronts are sharp on the outcrop and thin section scales, and are defined by the complete breakdown of antigorite to form talc and magnesite (Fig. 2a, d, g). In a Fe-free model system, the soapstone forming reaction can be simplified to:

$$
\begin{gathered}
2 \mathrm{Mg}_{3} \mathrm{Si}_{2} \mathrm{O}_{5}(\mathrm{OH})_{4}+3 \mathrm{CO}_{2, \mathrm{aq}} \rightarrow 3 \mathrm{MgCO}_{3} \\
\text { Serpentine } \\
\text { Magnesite } \\
+\underset{\mathrm{Mg}_{3} \mathrm{Si}_{4} \mathrm{O}_{10}(\mathrm{OH})_{2}}{ }+3 \mathrm{H}_{2} \mathrm{O} .
\end{gathered}
$$

The soapstone assemblage is stable at fluid $\mathrm{CO}_{2}$ activities between those stabilizing ophimagnesite (lower $a \mathrm{CO}_{2}$ ) and

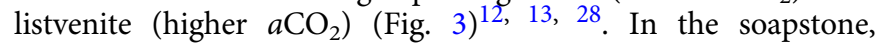




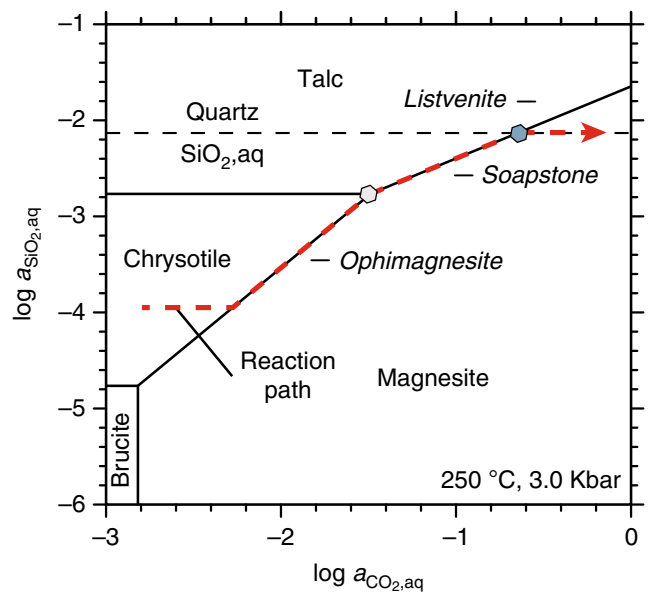

Fig. 3 Reaction path of serpentinite carbonation. $\mathrm{CO}_{2}-\mathrm{SiO}_{2}$ activity diagram in the system $\mathrm{MgO}-\mathrm{SiO}_{2}-\mathrm{H}_{2} \mathrm{O}-\mathrm{CO}_{2}$ showing the reaction path of progressive serpentinite carbonation resulting in ophimagnesite (serpentine + magnesite), soapstone (talc + magnesite), and listvenite (quartz + magnesite) formation at constant pressure and temperature. Hexagon symbols mark $\mathrm{CO}_{2}$ activity values used in Fig. 9. Mineral stability fields are calculated using the computer program Supcrt and thermodynamic database dprons 96. dat $^{50}$, quartz saturation is based on the thermodynamic data of Rimstidt ${ }^{51}$. The estimated pressure of $3 \mathrm{kbar}$ is based on a normal thermobaric gradient in a slightly thickened crust (12 bar $\left./{ }^{\circ} \mathrm{C}\right)^{52}$. The same diagram calculated for alteration temperatures of 180 ${ }^{\circ} \mathrm{C}$ and $300{ }^{\circ} \mathrm{C}$ is included in the supplement (Supplementary Fig. 1)

anhedral to subhedral magnesite is enclosed in a matrix composed of mainly talc and minor clinochlore (Fig. 4a-c). Magnetite is present as a matrix component, inclusions in magnesite and rims on large $(>100 \mu \mathrm{m})$ oxide grains that commonly comprise a $\mathrm{Cr}$-spinel or $\mathrm{Cr}$-magnetite core. Breakdown of Fe-bearing serpentine allows for magnetite formation in the soapstone in addition to magnetite inherited from the precursor serpentinite. Listvenite formation proceeds by dissolution of talc and precipitation of quartz and additional magnesite (in the simplified Fe-free system):

$$
\underset{\text { Talc }}{\mathrm{Mg}_{3} \mathrm{Si}_{4} \mathrm{O}_{10}(\mathrm{OH})_{2}}+3 \mathrm{CO}_{2, \mathrm{aq}} \rightarrow \underset{\text { Magnesite }}{3 \mathrm{MgCO}_{3}}+\underset{\text { Quartz }}{4 \mathrm{SiO}_{2}}+\mathrm{H}_{2} \mathrm{O}
$$

In contrast to soapstone and serpentinite, listvenite contains additional mica (biotite, Cr-muscovite), chlorite, albite, tourmaline, and sometimes sulfide phases (Fig. 2e, h). Magnetite is significantly less abundant or absent. Soapstone and listvenite magnesite are texturally and compositionally distinct. The reaction textures imply that euhedral listvenite magnesite overgrows preexisting, anhedral soapstone magnesite (Fig. 4). The core-rim interface resembles the crystal shape of magnesite in the soapstone. The core region of these composite grains frequently contains magnetite inclusions and has a high $\mathrm{X}_{\mathrm{Mg}}\left(\mathrm{X}_{\mathrm{Mg}}=\mathrm{Mg} /\right.$ $(\mathrm{Mg}+\mathrm{Fe}) \approx 0.93)$, whereas the euhedral magnesite rim is devoid of magnetite inclusions and distinctly enriched in $\mathrm{Fe}\left(\mathrm{X}_{\mathrm{Mg}} \approx 0.86\right)$ (Fig. 5) ${ }^{13}$.

Geophysical field survey. We conducted a multi-scale geophysical investigation across the carbonation fronts by integrating aeromagnetic data $(\sim 10 \mathrm{~km})$, total magnetic field and magnetic susceptibility surveys at outcrops $(10-100 \mathrm{~m})$, and magnetic mapping of thin sections $(\mu \mathrm{m})$ from drill core samples acquired along the survey lines. The crustal-scale aeromagnetic field data of the LUC region were obtained by the Norwegian Geological Survey's 1991 DRAGON aeromagnetic survey using a Scintrex MEP410 cesium magnetometer with an average survey altitude of $60 \mathrm{~m}$ and line spacing of $200 \mathrm{~m}$.

The aeromagnetic total field of the Linnajavri region exhibits small provinces with distinctive high amplitude, short-wavelength $(<100 \mathrm{~m})$ anomalies in contrast to the surrounding metasedimentary units, which exhibit only weak field values and minimal amplitude variations. The locations of high amplitude, shortwavelength anomalies coincide with the distribution of mapped ultramafic complexes (Fig. 1a-c). Outcrop-scale total field magnetic anomaly surveys were conducted using a highprecision Applied Physics fluxgate magnetic sensor across serpentinite soapstone (Fig. 6a, b) and soapstone- listvenite (Fig. 6d, e) reaction fronts. All total field aeromagnetic and outcrop-scale total field magnetic anomaly surveys were corrected for the International Geomagnetic Reference Field model- $12^{30}$. Magnetic susceptibility measurements were conducted along the magnetometry transects using a Terra-TK04 susceptometer (Fig. 6c, f). In contrast to total field magnetic anomaly measurements, susceptibility measurements only capture the surface $(\sim 2 \mathrm{~cm})$ mineralogy of the surveyed formation.

Changes in total field magnetic anomaly amplitudes over measurement profiles originate from the combination of both natural and induced remanent magnetization (NRM) of the rock formation, whereas changes in magnetic susceptibility values represent the abundance and chemical composition of magnetic carriers. In the serpentinite and soapstone samples magnetite represents the only magnetic carrier phase, while magnetite is absent in listvenite or present in only minor amounts with occasional additional iron sulfide phases (pyrite, chalcopyrite, and pyrrhotite) (Fig. 2f-h). Changes in total field anomaly and susceptibility wavelengths represent magnetic boundary spacing and the presence of different alteration assemblages separated by reaction fronts. Overall, the magnetic field measurements show distinctly higher amplitudes and shorter wavelengths in the soapstone relative to the adjacent serpentinite and listvenite formations (Fig. 6).

Outcrop-scale total magnetic field anomaly profiling also documents magnetic anomaly contrasts between the ultramafic and sedimentary units with less ambiguity. The "background" magnetic anomalies over the thick metasedimentary units are almost zero after the regional field correction, whereas both magnetic anomaly and susceptibility profiles across the serpentinite-soapstone and soapstone-listvenite fronts show marked changes in anomaly amplitudes and wavelengths. Along an idealized reaction path from low to high $a \mathrm{CO}_{2}$, magnetic anomaly amplitudes are high in serpentinite, and even higher in soapstone, but minimal in listvenite with little variations in amplitude and wavelength (Fig. 6b, e). Magnetic susceptibility profiles across serpentinite soapstone and soapstone-listvenite fronts follow this same trend in amplitude and wavelength variation (Fig. 6c, f), consistent with previously reported magnetic susceptibility observations ${ }^{10}$.

Thin section SQUID microscopy. Magnetic field mapping at sub millimeter-scale spatial resolution on representative thin sections from serpentinite, soapstone, and two listvenite samples acquired from two different localities at the LUC were conducted using a scanning superconducting quantum interference device (SQUID) microscope at the Massachusetts Institute of Technology Paleomagnetism Laboratory. The instrument's magnetic field sensitivity is $\sim 0.01 \mathrm{nT}$ and measures the vertical component of the magnetic field in a rectangular grid of positions above thin sections $^{31}$. NRM fields were measured on four thin sections 


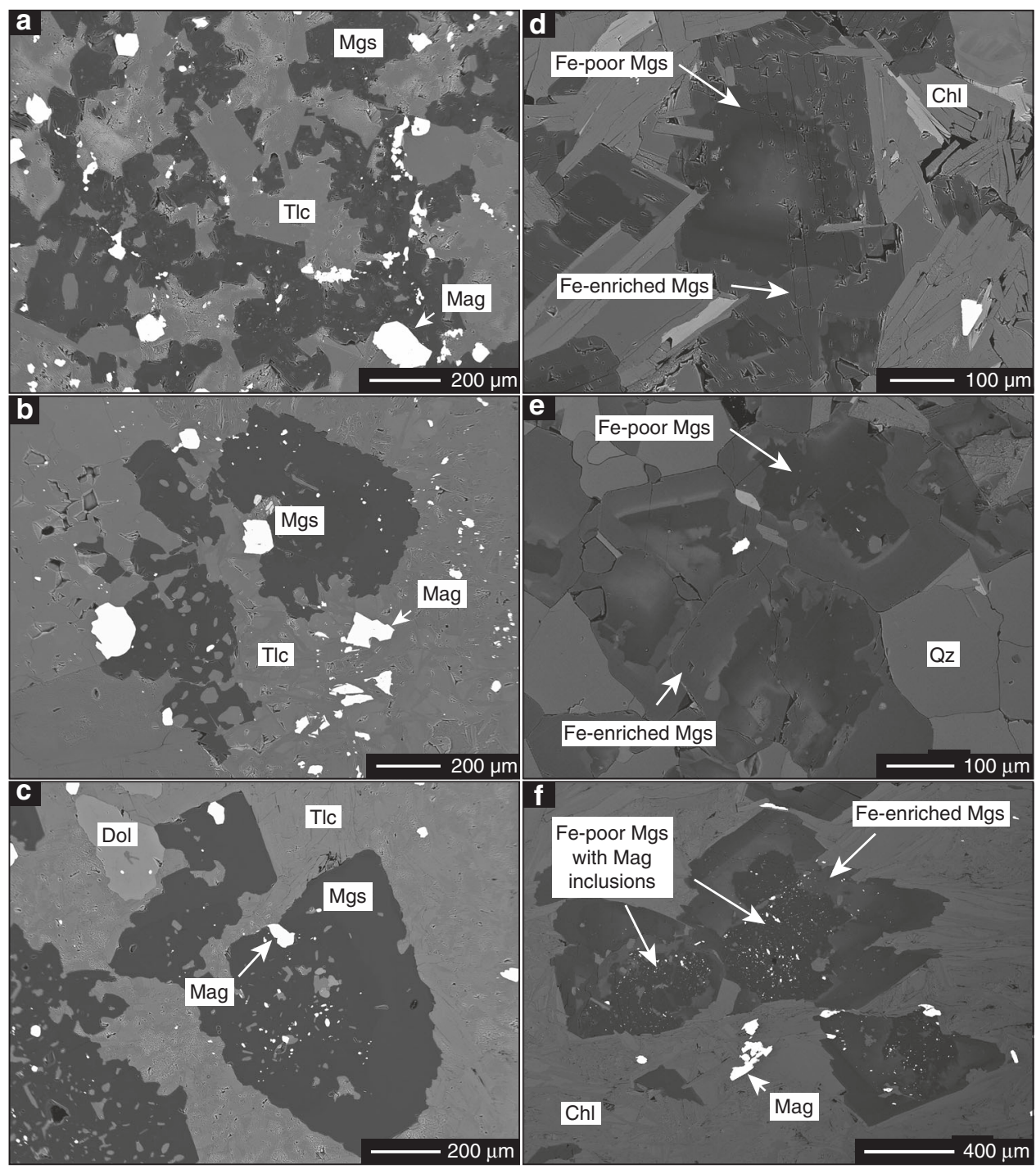

Fig. 4 Magnesite growth textures. Back-scattered electron (BSE) images showing magnesite textures in soapstone a-c and listvenite d-f. Anhedral to subhedral magnesite in the soapstone frequently contains magnetite inclusions, whereas euhedral magnesite rims related to listvenite formation are in most cases devoid of magnetite. The zonation of listvenite-magnesite is caused by elevated $\mathrm{Fe} / \mathrm{Mg}$ in the euhedral rim

representing each lithology at a sensor-to-sample distance of 170 $\mu \mathrm{m}$ and with $85 \mu \mathrm{m}$ line spacing. At the same imaging resolution, we also performed anhysteretic remanent magnetization (ARM) field measurements to assess the distribution of magnetic carriers within the samples at fine spatial scale. After full alternating-field demagnetization of the samples, we imparted ARMs with a bias field of $100 \mu \mathrm{T}$ and a peak alternating field of $260 \mathrm{mT}$ to activate magnetic sources in the low to high coercivity range and assess the capacity of the sample to acquire magnetization.

SQUID microscopy on LUC thin section samples support the outcrop-scale magnetic anomaly behavior in the serpentinite, soapstone, and listvenite assemblages: high $(\sim 6.7 \mu \mathrm{T})$ NRM magnetic field values in serpentinite, even higher $(\sim 9.4 \mu \mathrm{T})$ in the soapstone and almost none (except for a few grains of 1.8-3.0 $\mu \mathrm{T}$ per measured sample) in the listvenite (Fig. 7a). Petrographic observations confirm that these samples are consistent with previously described LUC field samples ${ }^{13}, 26 . \mathrm{CO}_{2}$ mass fractions of each sample used for thin section preparation were measured as $\sim 2.35 \mathrm{wt} \%, \sim 14.9 \mathrm{wt} \%$, and $\sim 29.3 \mathrm{wt} \%$ for serpentinite, soapstone, and listvenite, respectively, (Supplementary Table 1) 13. As observed in outcrop and thin section, listvenite formation can be heterogeneous in terms of mineral composition and reaction progress, which correlates with the breakdown of magnetite (e.g., Fig. 8). Listvenite samples-16 and -11 exemplify different stages of reaction progress (Fig. 7a). Sample listvenite-11 is completely altered and contains sulfide minerals and is devoid of magnetite, while listvenite-16 contains talc and magnetite relicts and represents incomplete alteration. The ARM magnetic field values of both listvenite samples exhibit this heterogeneity in the weakest magnetic field values among the two carbonation product assemblages. Magnetite inclusions in thermodynamically stable soapstone-magnesite are effectively passivated from further replacement reactions and together with rare sulphide minerals contribute to the weak magnetic field strength of the listvenite samples. Overall, ARM magnetic field values follow the same trend as the NRM, confirming that (i) the observed NRM in the thin section samples reflects a lithology dependent (i.e., abundance of magnetic carriers) magnetic source; (ii) a strong correlation exists with the amplitude and wavelength variations in magnetic field values; and (iii) NRM in our field samples reflects the behavior observed in total-field anomaly profiles and further link the observed changes in magnetic anomaly amplitudes and wavelengths to mineral carbonation reactions at the grain scale (Fig. $7 \mathrm{a}, \mathrm{b})$. 


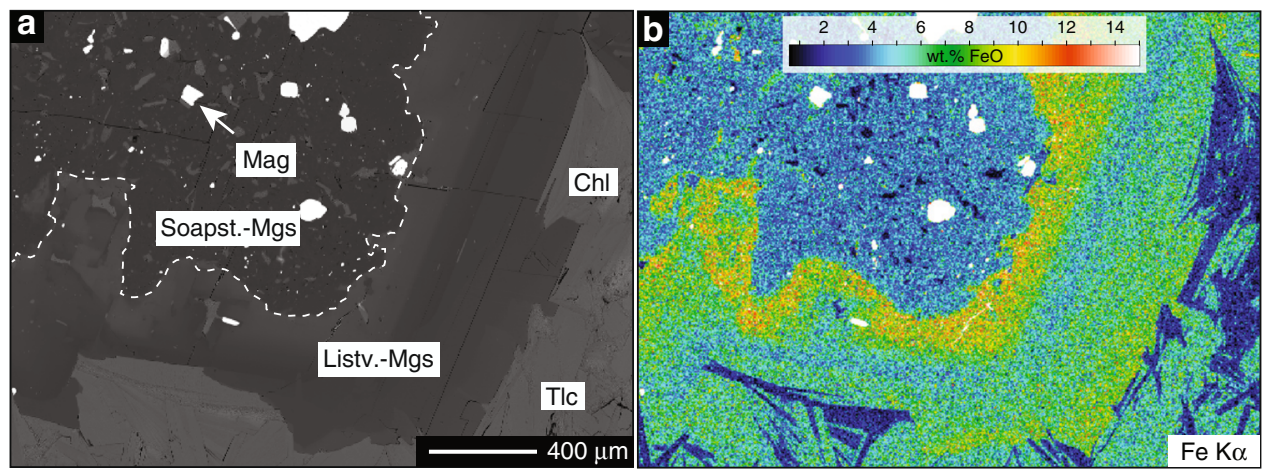

Fig. 5 Compositional zoning in listvenite magnesite BSE image. a and quantitative element map of zoned magnesite $\mathbf{b}$ in the listvenite showing the increase in $\mathrm{FeO}$ in the euhedral magnesite rim overgrowing a low $\mathrm{FeO}$, magnetite inclusion rich, anhedral magnesite core related to earlier soapstone formation
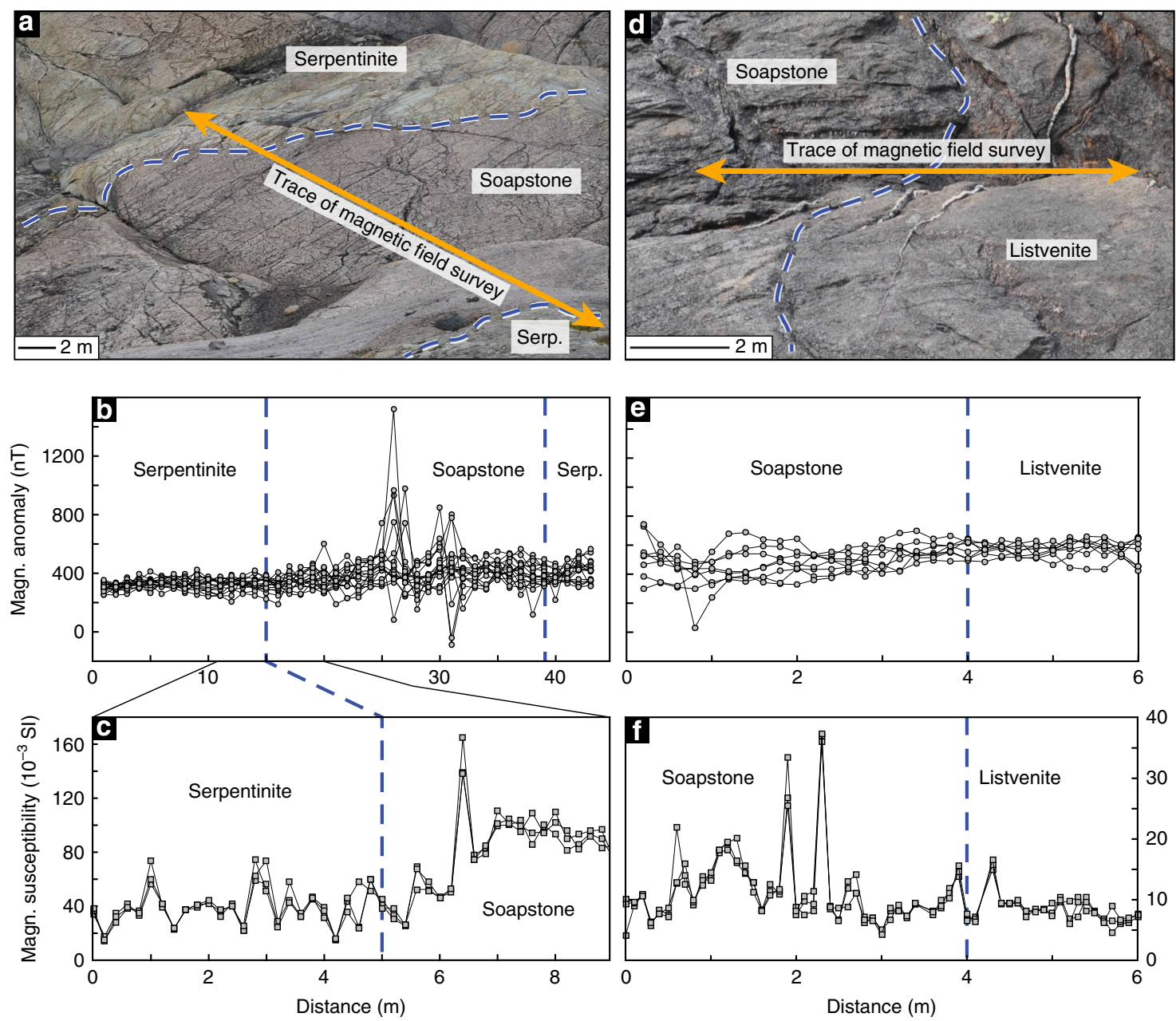

Fig. 6 Outcrop magnetic anomaly measurements. Outcrop scale total field and magnetic susceptibility mapping across the serpentinite-soapstone interface $\mathbf{a}$ and the soapstone-listvenite interface $\mathbf{d}$. Total magnetic field values across the serpentinite-soapstone interface were acquired along 16 transects (along the orange line in $\mathbf{a}$ ) with a sampling interval and line spacing of $0.6 \mathrm{~m}$ and $0.2 \mathrm{~m}$, respectively $\mathbf{b}$. A total of three magnetic susceptibility measurement profiles were acquired along a portion of the same transect $\mathbf{c}$. Total magnetic field values across the soapstone-listvenite interface were acquired along 8 transects (along the orange line in $\mathbf{d}$ ) with a sampling interval and line spacing of $0.2 \mathrm{~m} \mathbf{e}$. A total of three magnetic susceptibility measurement profiles were acquired along the same transect $\mathbf{f}$

Replacement reactions involving magnetic carrier minerals. Variations in the magnetic signal strength of the different alteration assemblages can be linked to the stability of magnetic carrier minerals at the relevant alteration conditions. Thermodynamic models and hydrothermal experiments predict an increasing abundance of magnetite during the alteration sequence from peridotite serpentinization, intermittently formed soapstone, to listvenite ${ }^{10,23,24}$. As a result, total magnetic field intensity is expected to increase along the isothermal carbonation reaction path, while the absolute magnetic field intensity value depends on the amount of magnetite formed and thus on alteration temperature. In the serpentinite and soapstone samples, 


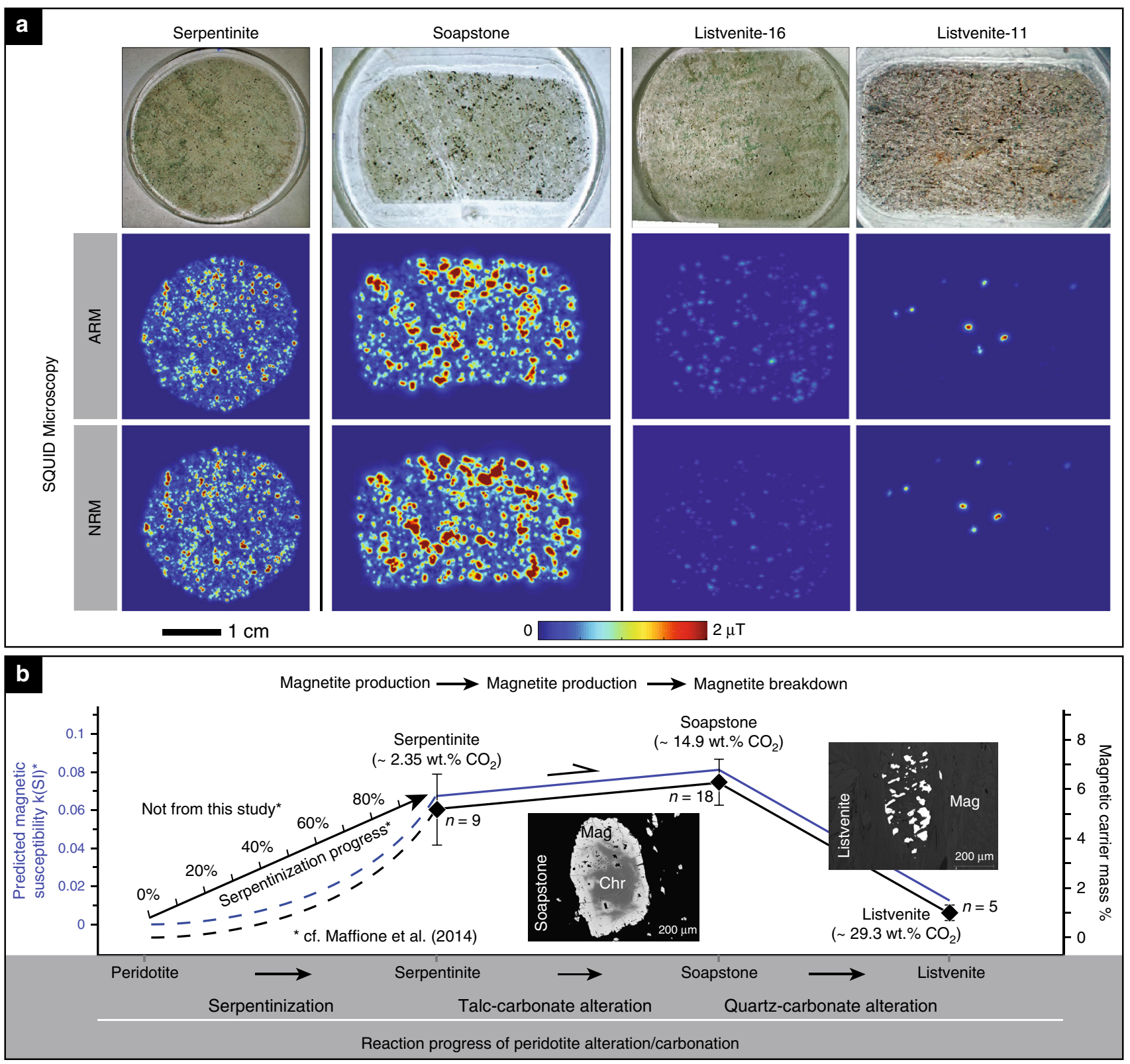

Fig. 7 Thin section magnetic anomaly measurements. a NRM and ARM (with the peak alternating field of $260 \mathrm{mT}$ and the DC bias field of $100 \mu \mathrm{T}$ ) in $30 \mu \mathrm{m}$ thickness thin sections of serpentinite, soapstone and two listvenite samples acquired by SQUID microscopy. The samples are mounted on 1-inch discs. Shown is the total magnetic field at a height of $170 \mu \mathrm{m}$ above the samples. For comparison, the SQUID images are presented with the color scale of 0-2 $\mu$ T (Note the grains in the serpentinite and soapstone samples are mostly $>2 \mu \mathrm{T}$ ). Listvenite samples show significantly weaker magnetic signal strength compared to serpentinite and particularly soapstone. Relict magnetite grains in the listvenite are mostly present as inclusions in magnesite cores and hence passivated from reaction during listvenite formation. $\mathbf{b}$ Schematic of changes in magnetite abundance and predicted magnetic field strength changes versus reaction progress of ultramafic rock serpentinization ${ }^{43}$ and carbonation. Magnetic susceptibility values are based on Maffione et al. ${ }^{43}$ and may differ in other alteration settings depending on rock composition and alteration temperature. Diamond symbols show the calculated bulk rock content of magnetite in the different alteration zones assuming bulk rock $\mathrm{Fe}^{3+}$ is exclusively present in magnetite (Supplementary Table 1). Error bars denote the $1 \sigma$ standard deviation of averaged bulk Fe ${ }^{3+}$ weight fractions

magnetite is the only mineral phase contributing to the magnetic signal, whereas listvenite sometimes contains additional sulfide minerals (pyrite, chalcopyrite, pyrrhotite) (Fig. 2f-h). Magnetite precipitates and dissolves depending on the availability of dissolved $\mathrm{Fe}$ and its thermodynamic stability along the reaction path (Figs 3,9$)^{32}$ and the distribution of Fe between secondary phases is controlled by their $\mathrm{Fe}-\mathrm{Mg}$ exchange potentials $\left(\Delta \mu\left(\mathrm{Fe}^{2+} \mathrm{Mg}_{-1}\right)\right)$ 23 . For the dominant silicate phases involved in ultramafic rock carbonation, preferential uptake of $\mathrm{Fe}$ is in the order: olivine $>$ antigorite $>$ talc $^{33,34}$. Alteration of peridotite to form serpentinite and soapstone is therefore accompanied by release of Fe that is not partitioned into secondary serpentine and talc but available for magnetite formation:

$$
3 \mathrm{FeO}+0.5 \mathrm{O}_{2} \rightarrow \mathrm{Fe}_{3} \mathrm{O}_{4} .
$$

The increase in magnetite abundance and the composition of secondary silicate (talc $\mathrm{X}_{\mathrm{Mg}} \approx 0.95$; chlorite $\mathrm{X}_{\mathrm{Mg}} \approx 0.92$ ) and carbonate phases (magnesite $\mathrm{X}_{\mathrm{Mg}} \approx 0.93$ ) in soapstone relative to serpentinite (antigorite $\mathrm{X}_{\mathrm{Mg}} \approx 0.94$ ) is thus consistent with the thermodynamic prediction and reflected by magnetic field 
intensity variations in outcrop and thin section-scale magnetic mapping across serpentinite-soapstone interfaces (Figs. 6b, 7a).

However, decreasing magnetic field intensity across the soapstone-listvenite front (Fig. 6e) and the breakdown of magnetite in listvenite as observed in thin section analysis (Fig. 7a) and e.g., by Hansen et al. ${ }^{16}$ contradicts model predictions 24,32 . This suggests that listvenite formation involves formation of non-magnetic minerals at the expense of magnetite. The presence of magnetite in the samples prior to listvenite formation is supported by dissolution textures of oxide phases present as small individual grains of $<10 \mu \mathrm{m}$ in diameter, forming clusters mimicking the size and shape of larger precursor grains identical to those present in the soapstone (Fig. 8). Furthermore, magnetite inclusions in the core of listvenite-magnesite indicate its stability in the soapstone prior to the growth of inclusion-free, $\mathrm{Fe}-$ enriched magnesite rims during listvenite formation (Figs. 4f, 5). Magnetite breakdown releases two $\mathrm{Fe}^{3+}$ ions for each $\mathrm{Fe}^{2+}$ ion and additional small amounts of $\mathrm{Fe}^{3+}$ may be released from breakdown of serpentine and talc. Secondary sheet silicate (talc, mica, and chlorite), carbonate (as siderite component), and sulfide (pyrite, pyrrhotite) phases predominantly incorporate $\mathrm{Fe}^{2}$ ${ }^{+}$, while talc and chlorite may take up small amounts of $\mathrm{Fe}^{3+}$. At the high fluid $\mathrm{CO}_{2}$ activities required to stabilize the listvenite assemblage, siderite forms at the expense of magnetite thereby effectively reducing the released ferric Fe (Fig. 9):

$$
\underset{\text { Magnetite }}{\mathrm{Fe}_{3} \mathrm{O}_{4}}+3 \mathrm{CO}_{2} \rightarrow \underset{\text { Siderite }}{3 \mathrm{FeCO}_{3}}+0.5 \mathrm{O}_{2} .
$$

The change in iron oxidation state during serpentinite carbonation is reflected by bulk rock $\mathrm{Fe}^{2+} / \mathrm{Fe}^{3+}$ of $\sim 1.19$ in serpentinite, $\sim 0.86$ in soapstone, and $\sim 11.5$ in the listvenite (Supplementary Table 1$)^{13}$. Siderite represents the Fe component in $\mathrm{Fe}$ enriched and magnetite-free listvenite-magnesite overgrowing earlier formed low $\mathrm{Fe} / \mathrm{Mg}$ soapstone-magnesite. Magnetite breakdown is likely enhanced by reductive dissolution in the presence of dissolved reduced sulfur species $\left(\mathrm{H}_{2} \mathrm{~S} \text { and } \mathrm{HS}^{-}\right)^{35,36}$,

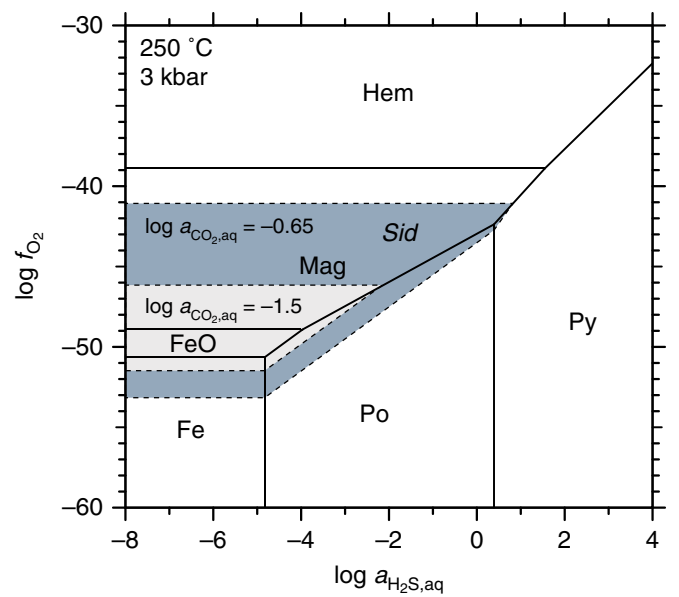

Fig. 9 Thermodynamic stability of magnetic signal carrier minerals. $\mathrm{H}_{2} \mathrm{~S}_{-} \mathrm{O}_{2}$ activity diagram in the system $\mathrm{Fe}-\mathrm{O}_{2}-\mathrm{H}_{2} \mathrm{~S}$ showing the stability of native iron, iron oxide and iron sulfide phases as a function of fluid $\mathrm{H}_{2} \mathrm{~S}$ activity and oxygen fugacity. The shaded areas indicate stability of siderite over native iron, iron oxide and iron sulfide phases at fluid $\mathrm{CO}_{2}$ activities corresponding to soapstone (gray field) and listvenite (dark gray field) formation (hexagon symbols in Fig. 3). The magnetite stability field is significantly reduced relative to siderite at a fluid $\mathrm{CO}_{2}$ activity that stabilizes the listvenite assemblage. The diagram was calculated using the computer program Supcrt and thermodynamic database dprons96.dat ${ }^{50}$. The same diagram calculated for alteration temperatures of $180^{\circ} \mathrm{C}$ and $300^{\circ} \mathrm{C}$ is included in the supplement (Supplementary Fig. 2)

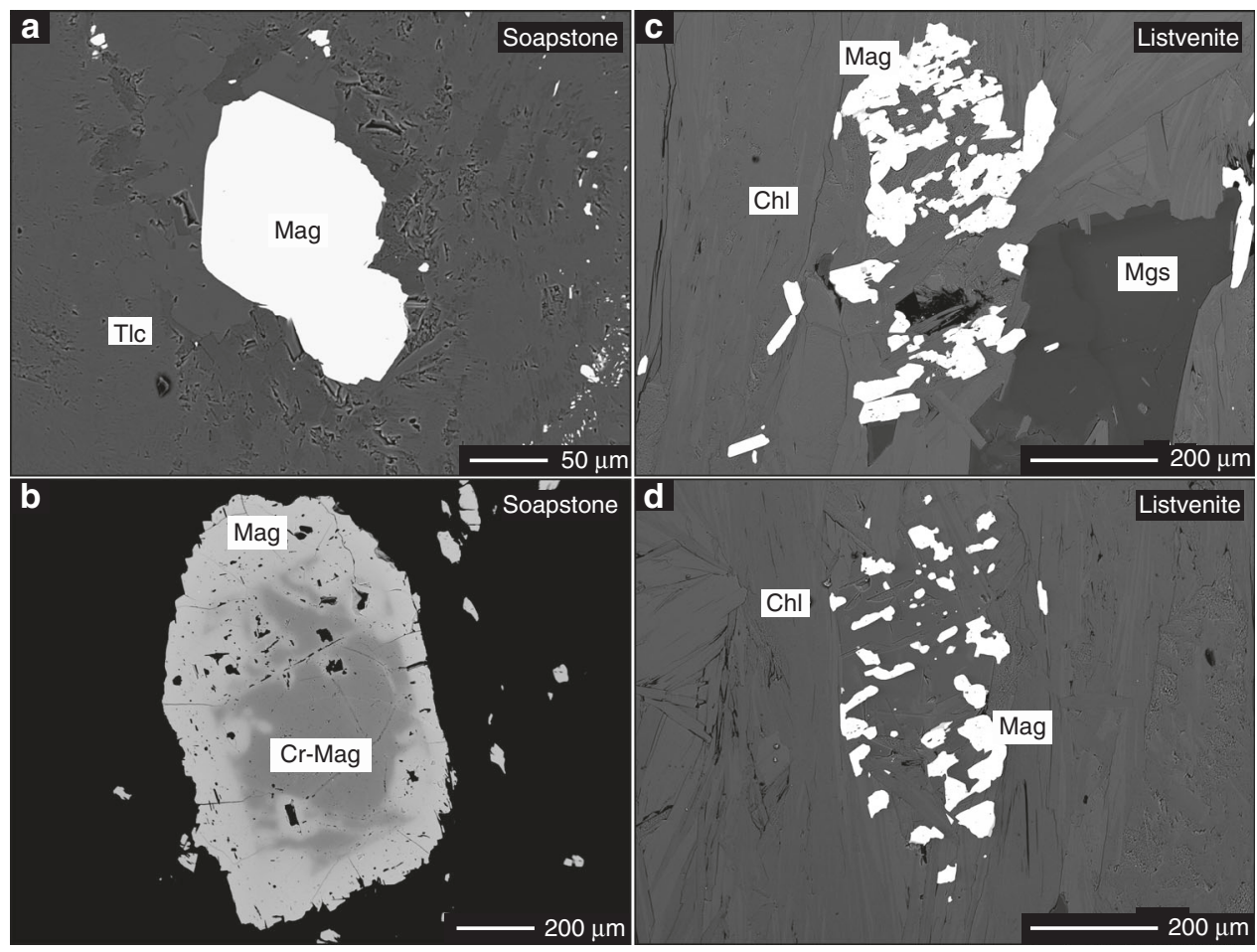

Fig. 8 Reaction textures of magnetic carrier minerals. BSE images showing a comparison of magnetite textures between soapstone $\mathbf{a}$ and $\mathbf{b}$ and listvenite $\mathbf{c}$ and $\mathbf{d}$. Magnetite in the soapstone is coarse grained and exhibits a subhedral crystal shape. In contrast, magnetite in the listvenite is usually fine grained with individual grains forming clusters that outline the size and shape of magnetite in the soapstone. Soapstone magnetite typically contains a chromium-bearing magnetite (Cr-Mag) core $\mathbf{b}$ 
providing charge balance and sulfur for the formation of sulfide phases in the listvenite (Figs. 2h, 9). Textural observations reveal that sulfide-bearing listvenite is almost devoid of magnetite whereas magnetite relicts are commonly preserved in samples without sulphide (Figs. 4f, 8c, d). Involvement of reduced organic carbon in driving ferric iron reduction is ruled out based on the ${ }^{13} \mathrm{C}$ enriched isotopic signature of magnesite ${ }^{13}, 37,38$.

\section{Discussion}

The baseline for magnetic signal changes during serpentinite carbonation is defined by the magnetite content of the serpentinite and is strongly dependent on the serpentinization progress and temperature, in addition to the composition of the precursor peridotite (e.g., variation in orthopyroxene content) and alteration fluid (e.g., silica activity) ${ }^{39-43}$. Hence, the magnetic signal of different serpentinite occurrences is likely to be different from the LUC $^{43}$. The stability of magnetite during subsequent carbonation is also dependent on the alteration fluid composition and temperature, which has been higher at the LUC than the inferred optimal carbonation temperature of olivine and heat-treated serpentine minerals ${ }^{3}, 12$. At a lower carbonation temperature silicate minerals may incorporate more iron thus reducing the amount of magnetite formed. However, carbonation-related changes in magnetite abundance at different temperatures will still allow for monitoring of the carbonation reaction progress even if absolute magnetic field strength and susceptibility of the starting material are offset to higher or lower values relative to this study (Supplementary Figs. 1, 2).

The aeromagnetic and field measurements, supported by SQUID microscopy and petrographic and geochemical assessment of the rock samples, allow us to draw a strong correlation between reaction-induced changes in the abundance of magnetic minerals and the amplitude, wavelength and wavelength variations in the remotely observed magnetic field values. The strong correlation of changes in magnetic field intensity with increasing bulk rock $\mathrm{CO}_{2}$ mass fractions from serpentinite $(\sim 2.35 \mathrm{wt} \%)$ to soapstone $(\sim 14.9$ $\mathrm{wt} \%)$ and to listvenite $(\sim 29.3 \mathrm{wt} \%)$ demonstrates that measureable geophysical signals are associated with changes in mineralogy during the carbonation sequence (Fig. $7 \mathrm{~b}$ ). The breakdown of magnetite during listvenite formation is consistent with observations at other locations ${ }^{16,44,45}$ suggesting that the decrease in magnetic field intensity is a common consequence of intense ultramafic rock carbonation. These observations imply that remote magnetic sensing can be effectively utilized for delineating the extent and degree of serpentinite carbonation and investigating active carbonation reactions through time by periodically measuring the static magnetic field intensity, e.g., at magnetic stations and in boreholes. While natural serpentinite carbonation may take place during metamorphic cooling, the isothermal reaction path of the LUC is likely consistent with $\mathrm{CO}_{2}$ mitigation schemes as cooling rates in relatively deep situated ultramafic target rocks are slow relative to the required $\mathrm{CO}_{2}$ injection rates and the exothermic carbonation reaction may balance cooling resulting from fluid injection ${ }^{3}$. Furthermore, knowledge of carbonation temperature and fluid pressure at depth can be obtained from injection well measurements and provide crucial parameters for the correct interpretation of magnetic signal changes.

\section{Methods}

Electron probe micro analysis. Quantitative elemental maps were acquired on a JEOL $8530 \mathrm{~F}$ electron microprobe equipped with 5 tunable wavelength dispersive spectrometers. Operating conditions were $40^{\circ}$ takeoff angle, and a beam energy of $15 \mathrm{keV}$. The beam current was $20 \mathrm{nA}$ for calibration and map acquisition. The beam diameter was $2 \mu \mathrm{m}$. Dwell time was $40 \mathrm{~ms}$ per pixel with a pixel dimension of $2 \times 2 \mu \mathrm{m}$. Elements were acquired using analyzing crystals $\mathrm{LiFH}$ for $\mathrm{Ti} \mathrm{K} \alpha 1, \mathrm{Cr}$ $\mathrm{K} \alpha 1, \mathrm{Mn} \mathrm{K} \alpha 1$, LiF for Fe K $\alpha 1$, Ni K $\alpha 1$, PETJ for Ca K $\alpha 1, \mathrm{~K} \mathrm{~K} \alpha 1$, and TAP for Mg $\mathrm{K} \alpha 1, \mathrm{Si} K \alpha 1, \mathrm{Al} \mathrm{K} \alpha 1$, and $\mathrm{Na} \mathrm{K} \alpha 1$. The standards were an assortment of synthetic and natural minerals and metals. The counting time was $20 \mathrm{~s}$ on peak for all elements, and Mean Atomic Number background corrects were used throughout ${ }^{46}$. The intensity data were corrected for Time Dependent Intensity (TDI) loss (or gain) using a self-calibrated correction for Si K $\alpha 1$, Na K $\alpha 1$, Ti K $\alpha 1, \mathrm{~K} K \alpha 1, \mathrm{Fe}$ K $\alpha 1$. Interference corrections were applied to Fe for interference by $\mathrm{Mn}$, and to $\mathrm{Mn}$ for interference by $\mathrm{Cr}^{47}$. Results are the average of three points and detection limits ranged from $0.006 \mathrm{wt} \%$ for Si K $\alpha 1$ to $0.008 \mathrm{wt} \%$ for $\mathrm{Al} \mathrm{K \alpha 1}$ to $0.009 \mathrm{wt} \%$ for $\mathrm{Na}$ $\mathrm{K} \alpha 1$ to $0.012 \mathrm{wt} \%$ for $\mathrm{Ti} \mathrm{K} \alpha 1$ to $0.028 \mathrm{wt} \%$ for $\mathrm{Ni} \mathrm{K} \alpha 1$. Oxygen was calculated by cation stoichiometry and included in the matrix correction. The elemental maps were processed using Probe Software's CalcImage application. The matrix correction method was $\mathrm{ZAF}$ and the mass absorption coefficients data set was LINEMU Henke $(\mathrm{LBL}, 1985)<10 \mathrm{KeV} / \mathrm{CITZMU}>10 \mathrm{KeV}$. The ZAF algorithm utilized was Armstrong/Love Scott ${ }^{48}$.

Whole-rock geochemical analyses. Whole-rock geochemical analyses including $\mathrm{CO}_{2}$ and $\mathrm{FeO}$ were performed by Actlabs Laboratories Ltd., using the lithium metaborate/tetraborate fusion ICP Whole Rock and the trace element ICP/MS packages.

Samples are mixed with a flux of lithium metaborate and lithium tetraborate and fused in an induction furnace. The melt is immediately poured into a solution of $5 \%$ nitric acid containing an internal standard, and mixed continuously until completely dissolved ( $\sim 30 \mathrm{~min})$. The samples are run for major oxides and selected trace elements on a combination simultaneous/sequential Thermo Jarrell-Ash ENVIRO II ICP or a Varian Vista 735 ICP. Calibration is performed using 7 prepared USGS and CANMET certified reference materials. One of the 7 standards is used during the analysis for every group of ten samples. FeO is determined through titration, using a cold acid digestion of ammonium metavanadate, and hydrofluoric acid in an open system. Ferrous ammonium sulphate is added after digestion and potassium dichromate is the titrating agent. Weight fractions of dry $\mathrm{CO}_{2}$ sample gas are measured by infrared absorption after decomposing $0.2 \mathrm{~g}$ of sample material in a resistance furnace in a pure nitrogen environment at $1000^{\circ} \mathrm{C}$, using an ELTRA CW-800 (www.actlabs.com).

Data availability. All the data generated or analyzed during this study are included in this published article (and its Supplementary Information files). Samples and data used in this study are available through MAPLES (Multiscale Applied Physics Lab for Earth Science) at Department of Geology and Geophysics, Texas A\&M University via email contact (masako.tominaga@tamu.edu).

Received: 10 December 2016 Accepted: 4 October 2017

Published online: 30 November 2017

\section{References}

1. Hacker, B. R. $\mathrm{H}_{2} \mathrm{O}$ subduction beyond arcs. Geochem. Geophys. Geosyst. 9, Q03001, doi:10.1029/2007GC001707 (2008).

2. Dasgupta, R. \& Hirschmann, M. M. The deep carbon cycle and melting in Earth's interior. Earth Planet Sci. Lett. 298, 1-13 (2010).

3. Kelemen, P. B. \& Matter, J. In situ carbonation of peridotite for $\mathrm{CO}_{2}$ storage Proc. Natl Acad. Sci. USA 105, 17295-17300 (2008).

4. Kelemen, P. B. et al. Rates and mechanisms of mineral carbonation in peridotite: natural processes and recipes for enhanced, in situ $\mathrm{CO}_{2}$ capture and storage. Annu. Rev. Earth Planet Sci. 39, 545-576 (2011).

5. Lackner, K. S., Wendt, C. H., Butt, D. P., Joyce, E. L. \& Sharp, D. H. Carbon dioxide disposal in carbonate minerals. Energy 20, 1153-1170 (1995).

6. Seifritz, W. $\mathrm{CO}_{2}$ disposal by means of silicates. Nature 345, 486-486 (1990).

7. Power, I. M., Wilson, S. A. \& Dipple, G. M. Serpentinite carbonation for $\mathrm{CO}_{2}$ sequestration. Elements 9, 115-121 (2013).

8. Andreani, M. et al. Experimental study of carbon sequestration reactions controlled by the percolation of $\mathrm{CO}_{2}$-rich brine through peridotites. Environ. Sci. Technol. 43, 1226-1231 (2009).

9. Hövelmann, J., Austrheim, H. \& Jamtveit, B. Microstructure and porosity evolution during experimental carbonation of a natural peridotite. Chem. Geol. 334, 254-265 (2012).

10. Malvoisin, B., Carlut, J. \& Brunet, F. Serpentinization of oceanic peridotites: 1 A high-sensitivity method to monitor magnetite production in hydrothermal experiments. J. Geophys. Res. 117, B01104, doi:10.1029/2011JB008612 (2012).

11. Hövelmann, J., Austrheim, H., Beinlich, A. \& Munz, I. A. Experimental study of the carbonation of partially serpentinized and weathered peridotites. Geochim. Cosmochim. Acta 75, 6760-6779 (2011).

12. Klein, F. \& Garrido, C. J. Thermodynamic constraints on mineral carbonation of serpentinized peridotite. Lithos 126, 147-160 (2011).

13. Beinlich, A., Plümper, O., Hövelmann, J., Austrheim, H. \& Jamtveit, B. Massive serpentinite carbonation at Linnajavri, N-Norway. Terra Nova 24, 446-455 (2012).

14. Cipolli, F., Gambardella, B., Marini, L., Ottonello, G. \& Zuccolini, M. V. Geochemistry of high-pH waters from serpentinites of the Gruppo di Voltri 
(Genova, Italy) and reaction path modeling of $\mathrm{CO}_{2}$ sequestration in serpentinite aquifers. Appl. Geochem. 19, 787-802 (2004).

15. Falk, E. S. \& Kelemen, P. B. Geochemistry and petrology of listvenite in the Samail ophiolite, Sultanate of Oman: complete carbonation of peridotite during ophiolite emplacement. Geochim. Cosmochim. Acta 160, 70-90 (2015).

16. Hansen, L. D., Dipple, G. M., Gordon, T. M. \& Kellett, D. A. Carbonated serpentinite (listwanite) at Atlin, British Columbia: A geological analogue to carbon dioxide sequestration. Can. Mineral. 43, 225-239 (2005).

17. Beinlich, A. \& Austrheim, $\mathrm{H}$. In situ sequestration of atmospheric $\mathrm{CO}_{2}$ at low temperature and surface cracking of serpentinized peridotite in mine shafts. Chem. Geol. 332, 32-44 (2012).

18. Beinlich, A., Austrheim, H., Glodny, J., Erambert, M. \& Andersen, T. B. $\mathrm{CO}_{2}$ sequestration and extreme $\mathrm{Mg}$ depletion in serpentinized peridotite clasts from the Devonian Solund basin, SW-Norway. Geochim. Cosmochim. Acta $\mathbf{7 4}$ 6935-6964 (2010).

19. Ulven, O. I., Beinlich, A., Hövelmann, J., Austrheim, H. \& Jamtveit, B. Subarctic physicochemical weathering of serpentinized peridotite. Earth Planet Sci. Lett. 468, 11-26 (2017).

20. Cushman, J. H. On measurement, scale, and scaling. Water Resour. Res. 22, 129-134 (1986).

21. Verdon, J. P., Kendall, J. M., White, D. J. \& Angus, D. A. Linking microseismic event observations with geomechanical models to minimise the risks of storing $\mathrm{CO}_{2}$ in geological formations. Earth Planet Sci. Lett. 305, 143-152 (2011).

22. White, A. F. \& Brantley, S. L. The effect of time on the weathering of silicate minerals: why do weathering rates differ in the laboratory and field? Chem. Geol. 202, 479-506 (2003).

23. Evans, B. W. Control of the products of serpentinization by the $\mathrm{Fe}^{2+} \mathrm{Mg}_{-1}$ exchange potential of olivine and orthopyroxene. J. Petrol. 49, 1873-1887 (2008).

24. Klein, F. et al. Iron partitioning and hydrogen generation during serpentinization of abyssal peridotites from $15^{\circ} \mathrm{N}$ on the Mid-Atlantic Ridge. Geochim. Cosmochim. Acta 73, 6868-6893 (2009).

25. Airo, M. L. Aeromagnetic and aeroradiometric response to hydrothermal alteration. Surv. Geophys. 23, 273-302 (2002).

26. Beinlich, A., Mavromatis, V., Austrheim, H. \& Oelkers, E. H. Inter-mineral Mg isotope fractionation during hydrothermal ultramafic rock alterationImplications for the global Mg-cycle. Earth Planet Sci. Lett. 392, 166-176 (2014).

27. Lindahl, I. \& Nilsson, L. P. Geology of the soapstone deposits of the Linnajavri area, Hamarøy, Nordland, north Norwegian Caledonides-Norway's largest reserves of soapstone. Geol. Soc., Geol. Sur. Nor. Spec. Publ. 11, 19-35 (2008).

28. Johannes, W. An experimental investigation of system $\mathrm{MgO}-\mathrm{SiO}_{2}-\mathrm{H}_{2} \mathrm{O}-\mathrm{CO}_{2}$. Am. J. Sci. 267, 1083-1104 (1969).

29. Korzhinskii, D. S. The theory of metasomatic zoning. Miner. Depos. 3, 222-231 (1968).

30. Thébault, E. et al. International Geomagnetic Reference Field: the 12th generation. Earth, Planets Space 67, 79 (2015)

31. Weiss, B. P., Lima, E. A., Fong, L. E. \& Baudenbacher, F. J. Paleointensity of the Earth's magnetic field using SQUID microscopy. Earth Planet Sci. Lett. 264, 61-71 (2007).

32. Frost, B. R. On the stability of sulfides, oxides, and native metals in serpentinite. J. Petrol. 26, 31-63 (1985).

33. Frost, B. R. \& Beard, J. S. On silica activity and serpentinization. J. Petrol. 48, 1351-1368 (2007).

34. Trommsdorff, V. \& Evans, B. W. Progressive metamorphism of antigorite schist in the Bergell tonalite aureole (Italy). Am. J. Sci. 272, 423-437 (1972).

35. Canfield, D. E. \& Berner, R. A. Dissolution and pyritization of magnetite in anoxic marine sediments. Geochim. Cosmochim. Acta 51, 645-659 (1987).

36. Dos Santos Afonso, M. \& Stumm, W. Reductive dissolution of iron(III) (hydr) oxides by hydrogen sulfide. Langmuir 8, 1671-1675 (1992).

37. Ohmoto, H., Watanabe, Y. \& Kumazawa, K. Evidence from massive siderite beds for a $\mathrm{CO}_{2}$-rich atmosphere before $\sim 1.8$ billion years ago. Nature $\mathbf{4 2 9}$, 395-399 (2004).

38. Palandri, J. L. \& Kharaka, Y. K. Ferric iron-bearing sediments as a mineral trap for $\mathrm{CO}_{2}$ sequestration: Iron reduction using sulfur-bearing waste gas. Chem. Geol. 217, 351-364 (2005).

39. Bach, W., Garrido, C. J., Paulick, H., Harvey, J. \& Rosner, M. Seawaterperidotite interactions: first insights from ODP Leg 209, MAR $15^{\circ} \mathrm{N}$. Geochem. Geophys. Geosyst. 5, 9 (2004).

40. Bach, W. et al. Unraveling the sequence of serpentinization reactions: petrography, mineral chemistry, and petrophysics of serpentinites from MAR $15^{\circ} \mathrm{N}$ (ODP Leg 209, Site 1274). Geophys. Res. Lett. 33, 1-4 (2006).

41. Frost, B. R., Evans, K. A., Swapp, S. M., Beard, J. S. \& Mothersole, F. E. The process of serpentinization in dunite from New Caledonia. Lithos 178, 24-39 (2013).

42. Klein, F. et al. Magnetite in seafloor serpentinite-some like it hot. Geology, Geology 42, 135-138 (2014).

43. Maffione, M., Morris, A., Plümper, O. \& van Hinsbergen, D. J. J. Magnetic properties of variably serpentinized peridotites and their implication for the evolution of oceanic core complexes. Geochem. Geophys. Geosyst. 15, 923-944 (2014).

44. Aftabi, A. \& Zarrinkoub, M. H. Petrogeochemistry of listvenite association in metaophiolites of Sahlabad region, eastern Iran: implications for possible epigenetic $\mathrm{Cu}-\mathrm{Au}$ ore exploration in metaophiolites. Lithos 156, 186-203 (2013).

45. Akbulut, M., Pişkin, Ö. \& Karayiğit, A. I. The genesis of the carbonatized and silicified ultramafics known as listvenites: a case study from the Mihalıççk region (Eskişehir), NW Turkey. Geol. J. 41, 557-580 (2006).

46. Donovan, J. \& Tingle, T. An improved mean atomic number background correction for quantitative microanalysis. Microsc. Microanal. 2, 1-7 (1996).

47. Donovan, J. J., Snyder, D. A. \& Rivers, M. L. An improved interference correction for trace element analysis. Microbe. Anal. 2, 23-28 (1993).

48. Armstrong J. T. Quantitative analysis of silicates and oxide minerals: comparison of Monte-Carlo, ZAF and Phi-Rho-Z procedures. In: Newbury, D. E., ed., Analysis Microbeam: San Francisco, California, San Francisco Press, p. 239-246 (1988).

49. Whitney, D. L. \& Evans, B. W. Abbreviations for names of rock-forming minerals. Am. Mineral. 95, 185-187 (2010).

50. Johnson, J. W., Oelkers, E. H. \& Helgeson, H. C. SUPCRT92: a software package for calculating the standard molal thermodynamic properties of minerals, gases, aqueous species, and reactions from 1 to 5000 bar and 0 to $1000{ }^{\circ}$ C. Comput. Geosci. 18, 899-947 (1992).

51. Rimstidt, J. D. Quartz solubility at low temperatures. Geochim. Cosmochim. Acta 61, 2553-2558 (1997).

52. Brown, M. Metamorphic patterns in orogenic systems and the geological record. Geol. Soc. Lond. Spec. Publ. 318, 37-74 (2009).

\section{Acknowledgements}

This project was supported by the Woods Hole Oceanographic Institution Independent Study Award (Tivey and Tominaga) and by NASA Astrobiology Institute NNA15BB02A (Tominaga). M.T. and A.B. are grateful to B. Jamtveit and H. Austrheim (University of Oslo) for their support during the 2011 and 2013 field campaigns. B.W. and E.A.L. thank the National Science Foundation grant DMS-1521765 and Thomas F. Peterson, Jr for generous support. We also thank the field work participants from Michigan State University and The University of Maryland for their perseverance in the barren field with challenging weather conditions. We especially would like to thank B.W. Evans at University of Washington for the discussion of redox reactions during listvenite formation. The authors acknowledge the facilities, and the scientific and technical assistance of the Australian Microscopy and Microanalysis Research Facility at the Centre for Microscopy, Characterisation and Analysis, The University of Western Australia, a facility funded by the University, State and Commonwealth Governments.

\section{Author contributions}

M.T. and M.A.T. designed the study. M.T., A.B. and B.A.H. jointly collected data in the field and wrote the paper. A.B. and Y.H. performed petrological and chemical analyses and interpreted the data. E.A.L. and B.W. performed the SQUID microscopy of field samples and interpreted data. Per style please provide conflict of interests statement.

\section{Additional information}

Supplementary Information accompanies this paper at doi:10.1038/s41467-017-01610-4

Competing interests: The authors declare no competing financial interests.

Reprints and permission information is available online at http://npg.nature.com/ reprintsandpermissions/

Publisher's note: Springer Nature remains neutral with regard to jurisdictional claims in published maps and institutional affiliations.

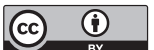

Open Access This article is licensed under a Creative Commons Attribution 4.0 International License, which permits use, sharing, adaptation, distribution and reproduction in any medium or format, as long as you give appropriate credit to the original author(s) and the source, provide a link to the Creative Commons license, and indicate if changes were made. The images or other third party material in this article are included in the article's Creative Commons license, unless indicated otherwise in a credit line to the material. If material is not included in the article's Creative Commons license and your intended use is not permitted by statutory regulation or exceeds the permitted use, you will need to obtain permission directly from the copyright holder. To view a copy of this license, visit http://creativecommons.org/ licenses/by/4.0/.

(c) The Author(s) 2017 